\section{OUR NATURAL HISTORY COLLECTIONS}

THE Bill to enable the trustees of the British Museum to remove the natural history collections to South Kensington, on which we commented in our issue of August I, has passed both Houses and virtually become law. The measure baving been introduced at a late period of the session, and hurried through all its stages, evidently for the express purpose of eluding observation, it could hardly have been expected that the result would have been otherwise. The assent of the Treasury was of course secured before the Bill was introduced, and it is by no means surprising that, what with Cyprus and Turkey, and the enormous pressure of other more interesting business, it was never discovered by the Government that the Bill was exactly contrary to the recommendations of the Royal Commission on Science. So far, therefore, the trustees have it all their own way, and are now authorised to continue at South Kensington the system of government that has made the state of our national natural history collections at Bloomsbury so long a byeword amongst naturalists. There remains, however, still one more chance of introducing some salutary reforms into the present system. Following on the authority to remove the collections, which the trustees have now obtained, money will be required to carry out the transfer, and to obtain the requisite funds a fresh application to Parliament will be necessary.

This application will, no doubt, be made in the ensuing session, but before it is complied with we trust that some sort of terms will be obtained from the trustees. In the first place they should be required to delegate the control of the New Natural History Museum to a small committee, in which should be included the two or three naturalists who now happen to be members of the trust. It is obvious that most of the great dignitaries of state and eminent noblemen who form the trustees of the British Museum, neither know nor care anything about natural history. Until recently, indeed, there has not been a single person who could fairly be called a naturalist on the trust. Lately, however, two excellent naturalists (Sir John Lubbock and Lord Walsingham) have become ordinary members of the trust, and Sir Joseph Hooker, as president of the Royal Society, is ex afficio one of the trustees. A committee consisting of these gentlemen and of a few others, who might be presumed to have some general acquaintance with the requirements of modern science, would, we need hardly say, completely command the confidence of naturalists, and would answer to the board of visitors, which the Royal Commission on Science in their Report suggested should be constituted to look after the director. In the second place the chief executive officer of the new museum should be appointed secretary to the trustees $a d$ hoc, and the estimates for the two buildings should be kept entirely separate. So long as there remains any sort of subordination of the natural history to the principal librarian, who is the sole executive officer of the trustees at Bloomsbury, the old policy will be continued. The natural history will be starved in order to feed the overgrown library, and the petty restrictions and regulations which have so long vexed the souls of the visitors to the British Museum will be continued at South Kensing- ton. The best chance of obtaining the necessary reforms lies in an entire change of administration, and for this reason it is much to be lamented that the recommendation of the Royal Commission on Science to place the New Museum of Natural History directly under the control of the Government has not been attended to. Still if the Trustees can be induced to commit the management of the new institution to a well-selected delegacy and to appoint a director free from the evil influence of Bloomsbury, there is every hope that our New Museum of Natural History may be worthy of the nation, and take rank with the sister institutions of Paris, Leyden, and Berlin.

\section{THE BRITISH ASSOCIATION}

\section{Dublin, Monday}

TO-DAY the Reception Room was opened in Trinity College, the Examination Hall being used for this purpose; and the doors were scarcely opened before a rush for tickets took place, and 500 associate tickets were sold in the course of two or three hours. As usual, the local honorary secretaries are working vigorously, and so far the arrangements they have made seem to be excellent; in fact, it is generally admitted that at few places has the British Association had so excellent a reception nor so convenient and complete accommodation. One feature in this meeting is the shilling lunch tickets, which every member can procure, and that entitles him to an excellent lunch, costing at least double the price of his ticket. The numerous foreign visitors have been lodged at the chief hotels, and private hospitality has been offered to the leading members of the Association who have announced their intention of being present.

With regard to a paragraph in a contemporary on the soreness which has been produced in Dublin by the cavalier treatment local scientific men have received from the Council of the Association, and stating that local papers would be withheld, we are able to contradict the latter part of this statement, although it cannot be denied that considerable umbrage has been given by the singular omission of some most distinguished local names from the first list of sectional officers; notably is this the case in Section G, Mechanical Science. But the list is stated to be incomplete, and doubtless the omissions will be repaired at the first meeting of the General Committee before these lines are published.

The guide-book which is issued to the Association has each year become a more and more important work, and that to Dublin is certainly the most complete and most carefully compiled of any that we have seen. Nine months ago a guide-book committee was formed, and this committee, after breaking up into different sections, has worked unremittingly to make their undertaking as accurate and complete as possible. No better editors could have been chosen than Professors MacAlister and $\mathrm{McNab}$, who, besides the distinguished position they hold in their own departments of zoology and botany, possess an intimate acquaintance with the topography and biology of the neighbourhood, and who, since the beginning of the year, have unsparingly devoted their time to their arduous editorial labours-labours that have been largely augmented by the unexpected and unfortunate delays on the part of the firm of printers to whom the MSS. was first sent months ago. Thus it comes about that a somewhat awkward division is made into two unequal parts; but the division is one created by the printers and not by the nature of the contents. It is right to add that the thanks of the Association are due to Messrs. Dollard for the energy and skill which they have shown in the final printing of the guide-book. The book is illustrated with three maps; the first is a ten-mile to the inch map of the County Dublin; the second an admirable 